\title{
Diversity and Dynamics of Populations of Mites in nectarine Trees (Prunus persica var. nucipersica) (Rosaceae)
}

\author{
Fernando Berton Baldo ${ }^{1}$, Adalton Raga ${ }^{1}$, Jeferson Luiz de Carvalho Mineiro ${ }^{2} \&$ Jairo Lopez de Castro $^{3}$ \\ ${ }^{1}$ Laboratory of Economic Entomology, Biological Institute Experimental Center, Brazil \\ ${ }^{2}$ Laboratory of Acarology, Biological Institute Experimental Center, Brazil \\ ${ }^{3}$ Regional APTA, Regional Center of Agribusiness Technological Development of the Southwest of the State of \\ São Paulo, Brazil \\ Correspondence: Fernando Berton Baldo, Laboratory of Economic Entomology, Biological Institute Experimental \\ Center, Rodovia Heitor Penteado Km 3, CEP 13092-543, Campinas-SP, Brazil. Tel: 55-19-32528342. E-mail: \\ fernandobaldo@gmail.com
}

Received: January 15, 2016 Accepted: January 31, 2016 Online Published: February 21, 2016

doi:10.5539/jps.v5n1p28 URL: http://dx.doi.org/10.5539/jps.v5n1p28

\begin{abstract}
The international literature does not provide much information about the incidence of species of mites in nectarine cultivars. The purpose of the present study was to determine diversity and dynamics of populations of mites and their interactions in different nectarine cultivars in the southwestern region of the State of São Paulo, Brazil. These mites were split into 15 families, 22 genders and 28 species. Aculus fockeui (Nalepa \& Trouessant) (Eriophyidae) was the most abundant species, with $90.2 \%$ of the mites collected. The populations of $A$. fockeui displayed specific periods with greater number of individuals. Phytoseiidae showed the highest richness of species. Ricoseius loxocheles (De Leon) and Euseius ho (De Leon) were the most abundant predators. Euseius ho population showed a positive correlation with rainfall.
\end{abstract}

Keywords: Acari, Aculus fockeui, Prunus sp., Rosaceae, stone fruit

\section{Introduction}

In cultivations of peaches and nectarines, species of mites may cause economic losses to production (Raseira \& Centellas-Quezada, 2003). In Prunus spp., the eriophyids Aculops berochensis (Keifer \& Delley), Aculus fockeui (Nalepa \& Trouessant), Diptacus gigantorhyncus (Nalepa) and Eriophyes insidiosus (Keifer \& Wilson) are mentioned as being of economic importance (Castagnoli \& Oldfield, 1996).

Aculus fockeui is considered the most critical species in cultivation of peach trees because it causes yellowish stains on leaves, small deformations or curling. In severe infestations, this eriophyid mite reduces fruit production and quality (Flechtmann, 1979; Jeppson, Keifer \& Baker, 1975; Keifer, Baker, Kono, Delfinado, \& Styer, 1982).

In the far west region of the State of São Paulo, Tetranychidae mites were seen in several peach cultivars (Montes, Raga, Boliani, Mineiro, \& Santos, 2011, 2012). In nectarine and peach trees, Tetranychus urticae (Koch) attacks the underside of leaves, and causes damage that lead to leaf shedding (Gallo et al., 2002). Large populations of A. fockeui, Mononychellus planki (McGregor), T. urticae and phytoseiidae Euseius citrifolius Denmark \& Muma and Euseius concordis (Chant) were found in leaves of several peach cultivars in the west of the State of São Paulo (Montes et al., 2012).

Unlike the number of records in the literature about mites in peach trees, there is little information about mite fauna in nectarine trees. As a consequence, the purpose of the present research was to determine the mite fauna in nectarine trees, to assess the relationships among the key species of phytophagous and predatory mites, and to analyze the influence of rainfall and temperature on the populations of such mites.

\section{Material and Methods}

2.1 Study Area

The research was conducted at the Germplasm Bank of Temperate and Subtropical Climate Fruit Trees of the Agronomic Institute, located at the municipality of Capão Bonito, State of São Paulo, Brazil 
(S242'24.65",W48²3'3.54"O, $730 \mathrm{~m})$.

The nectarine trees were part of a mixed orchard set up in 1993, comprising peach, plum and nectarine tops on root-stocks of the Okinawa cultivar, covering a total area of $2,415 \mathrm{~m}^{2}$, with 34 different genetic materials with two plants per cultivar. Plants showed approximately three meters high, spacing between plants was $5.0 \times 3.0 \mathrm{~m}$ (668 plants per ha) (Barbosa, Ojima, Campo-DallOrto, \& Martins, 1993). During the study, no pesticide was used for pest management. The orchard was performed only by pruning and mechanical cleaning for weed control.

Three cultivars of economically representative nectarine trees for fruit-growing in São Paulo were used in the present research: Colombina (Fla. 1937-S), Josefina (IAC N 1579-1) and Rubro-Sol (Rigitano, Ojima, \& Campo-Dall'orto, 1975; Ojima et al., 1986).

\subsection{Sampling}

Mites were sampled biweekly from January 2004 to March 2006. The sampling included random collection of 30 leaves of the middle third of the plants from each cultivar. The collected leaves of each cultivar were placed in individual paper bags. The leaves of each sample were transferred to $500-\mathrm{ml}$ glass bottles with $70 \%$ alcohol for preservation. Next the mites were extracted at the laboratory. Hoyer's medium was used to set most mites on the slides, except for eriophyid mites mounted in modified Berlese medium (Jeppson et al., 1975).

The mites were identified with the help of a phase-contrast optical microscope with 100x augmentation. "Voucher species" were deposited in the "Geraldo Calcagnolo" Reference Collection of Mites of Agricultural Importance (ICMBio 35919-1) at the Acarololgy Laboratory of the Experimental Center of the Biological Institute (CEIB), in Campinas, SP, Brazil.

The data on temperature and precipitation were obtained from the Meteorological Station of APTA (São Paulo Agency of Agribusiness Technology) Capão Bonito Regional Office, installed approximately $250 \mathrm{~m}$ far from the study area.

\subsection{Statistical Analyses}

Pearson linear correlation analyses were conducted with $5 \%$ significance level to assess the influence of precipitation and temperature on the population dynamics of the species of phytophagous and predatory mites, and also possible interactions among these groups, using the BioEstat 5.0 statistical program (M. Ayres, J. M. Ayres, D. L. Ayres, \& Santos, 2007).

The mite abundance of each cultivar was analyzed by Tukey test ( $>0.05)$ using the ASSISTAT 7.7 program (Silva \& Azevedo, 2006). To do so, the data of the four most representative species were used during the study, two phytophagous species and two predatory species.

The PAST program was used to perform H' diversity analysis and cluster analysis (Hammer, Harper, \& Ryan, 2001).

The relative frequency was noted in percentage, obtained by the ratio of the number of samples with the occurrence of the respective species and the total number of samples. The abundance corresponds to the total number of individuals of each recovered species from the nectarine leaves during the whole period of the experiment.

\section{Results}

A total of 19,297 mites was found, split in 14 families, 22 genera and 28 species. In general, the number of mites recovered from Colombina $(4,801)$ and Josefina $(4,326)$ cultivars was similar, accounting for $25 \%$ and $22 \%$ of the total mites, respectively. In the case of Rubro-Sol cultivar $(10,170)$, the number of specimens was larger than all the other cultivars together, and accounted for $53 \%$ of all mites recovered (Table 1 ).

Colombina and Josefina cultivars displayed the same number of species (19), whereas for Rubro-Sol cultivar, 22 species were found (Table 1). Colombina and Josefina cultivars were similar, with similar diversity indexes $\left(\mathrm{H}^{\prime}\right)$ ( 0.55 and 0.54 respectively) and different from Rubro-Sol cultivar ( 0.31$)$. With the t-test, it was possible to verify that the diversity index of Rubro-Sol cultivar was significantly different from the other cultivars: $t=10,607$ and $p=4,266$ between Colombina, $t=-12,896$ and $p=9,683$ for Josefina cultivar, whereas the t-test between Colombina and Josefina cultivars indicated: $t=0.614$ and $p=0.538$, which confirm the similarity between the two cultivars. 
Table 1. Frequency, abundance, diversity ( $\left.\mathrm{H}^{\prime}\right)$ and species richness recovered from cultivars of nectarines Colombina (C), Josefina (J) and Rubro-sol (RS). Capão Bonito, SP, Brazil

\begin{tabular}{|c|c|c|c|c|c|c|c|c|}
\hline \multirow{2}{*}{ Family } & \multirow{2}{*}{ Species } & \multicolumn{3}{|c|}{ Frequency $(\%)$} & \multicolumn{3}{|c|}{ Abundance } & \multirow{2}{*}{ Total } \\
\hline & & $\mathrm{C}$ & $\mathrm{J}$ & RS & $\mathrm{C}$ & $\mathrm{J}$ & RS & \\
\hline Acaridae & Tyrophagus putrescentiae (Schrank) & 6.25 & 8.33 & 14.58 & 4 & 6 & 12 & 22 \\
\hline Cunaxidae & Armascirus sp. & 2.08 & - & - & 1 & - & - & 1 \\
\hline Echimyopodidae & Blomia sp. & 4.17 & - & 6.25 & 15 & - & 4 & 19 \\
\hline Eriophyidae & Aculus fockeui (Nalepa \& Trouessant) & 54.17 & 45.83 & 45.83 & 4,029 & 3,797 & 9,583 & 17,409 \\
\hline Iolinidae & Parapronematus acaciae Baker & 2.08 & 6.25 & 4.17 & 2 & 4 & 2 & 8 \\
\hline Melicharidae & Proctolaelaps sp. & - & 6.25 & 2.08 & - & 3 & 1 & 4 \\
\hline Oripodidae & Oripoda sp. & 2.08 & - & - & 1 & - & - & 1 \\
\hline \multirow[t]{13}{*}{ Phytoseiidae } & Amblyseius chiapensis De Leon & 4.17 & 4.17 & 4.17 & 2 & 3 & 2 & 7 \\
\hline & Amblyseius compositus Denmark \& Muma & 4.17 & 8.33 & 8.33 & 6 & 6 & 5 & 17 \\
\hline & Amblyseius herbicolus (Chant) & 14.58 & 31.25 & 14.58 & 9 & 37 & 10 & 56 \\
\hline & Euseius alatus De Leon & 12.50 & 10.42 & 14.58 & 10 & 9 & 21 & 40 \\
\hline & Euseius concordis (Chant) & 2.08 & - & - & 1 & - & - & 1 \\
\hline & Euseius ho (De Leon) & 27.08 & 22.92 & 31.25 & 25 & 29 & 43 & 97 \\
\hline & $\begin{array}{l}\text { Iphiseiodes matatlanticae Mineiro, Castro } \\
\& \text { Moraes }\end{array}$ & 4.17 & 2.08 & 2.08 & 3 & 1 & 1 & 5 \\
\hline & $\begin{array}{l}\text { Iphiseiodes saopaulus (Denmark \& } \\
\text { Muma) }\end{array}$ & 14.58 & 16.67 & 18.75 & 7 & 9 & 16 & 32 \\
\hline & Neoseiulus anonymus (Chant \& Baker) & - & 2.08 & - & - & 1 & - & 1 \\
\hline & Neoseiulus idaeus Denmark \& Muma & - & - & 2.08 & - & - & 1 & 1 \\
\hline & Phytoseiulus macropilis (Banks) & 4.17 & 8.33 & 2.08 & 7 & 4 & 4 & 15 \\
\hline & Ricoseius loxocheles (De Leon) & 6.25 & 10.42 & 12.50 & 4 & 73 & 101 & 178 \\
\hline & Typhlodromus transvaalensis (Nesbitt) & 4.17 & 2.08 & - & 2 & 1 & - & 3 \\
\hline Stigmaeidae & Agistemus sp. & - & - & 2.08 & - & - & 1 & 1 \\
\hline Tarsonemidae & Fungitarsonemus sp. & - & - & 2.08 & - & - & 1 & 1 \\
\hline & Tarsonemus confusus Ewing & - & 4.17 & 6.25 & - & 2 & 4 & 6 \\
\hline Tenuipalpidae & Brevipalpus sp. & - & 2.08 & 2.08 & - & 1 & 1 & 2 \\
\hline Tetranychidae & Tetranychus urticae Koch & 68.75 & 41.67 & 45.83 & 672 & 338 & 325 & 1,335 \\
\hline Tydeidae & Lorryia sp. & - & - & 2.08 & - & - & 2 & 2 \\
\hline & Pretydeus sp. & 2.08 & - & - & 1 & - & - & 1 \\
\hline Winterschmidtiidae & Oulenzia sp. & - & 2.08 & 2.08 & - & 2 & 30 & 32 \\
\hline & Colombina & & Rubro-sc & & & & & \\
\hline Species richness & 19 & & 22 & & & & & \\
\hline Diversity H' & 0.55 & & 0.31 & & & & & \\
\hline
\end{tabular}

The scheme shown in the dendrogram of Figure 1 corroborates the results seen in the diversity index H' and the t-test, with formation of two clusters. The first cluster is formed by species of mites found only in Rubro-Sol cultivar. The second cluster is formed by species of mites of the two other cultivars, which were similar in the foliar mite fauna. 

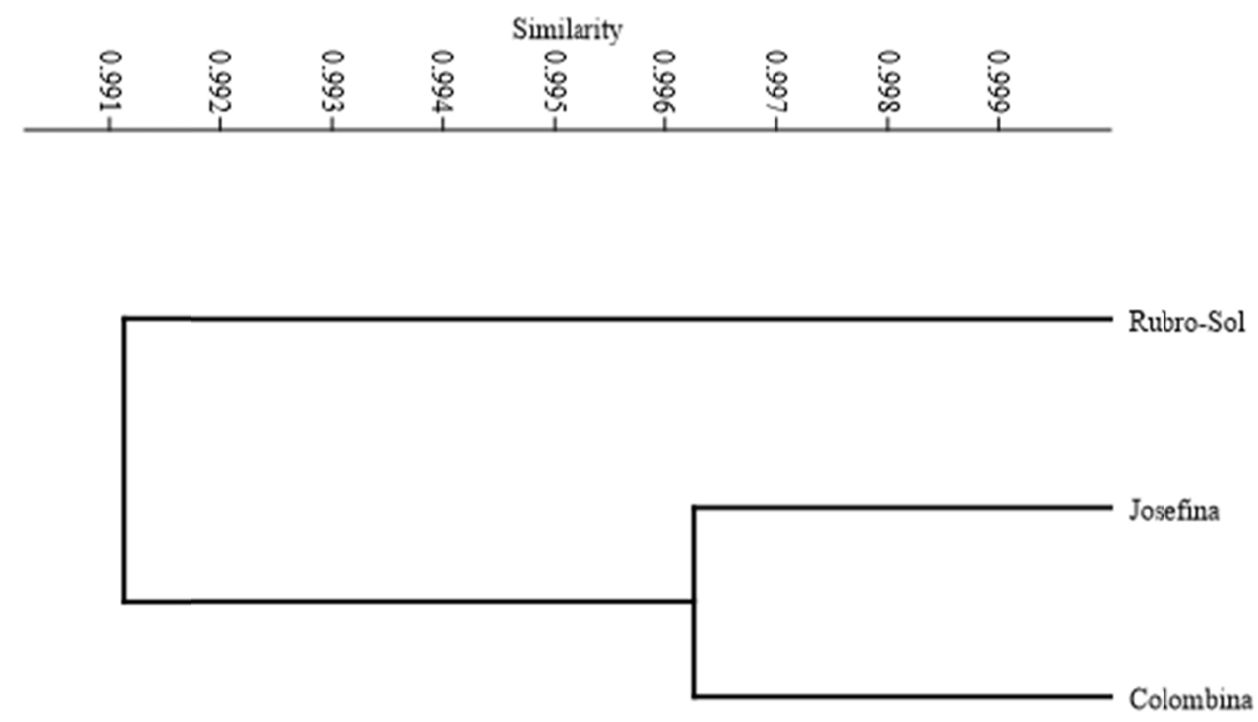

Figure 1. Dendrogram based on the similarity of mite diversity recovered from nectarine cultivars 'Colombina', 'Josefina' and 'Rubro-sol'. Capão Bonito, SP, Brazil

\subsection{Mite diversity}

Due to the large diversity of mites obtained from the three cultivars under study, it was possible to group them in conformance with their respective eating habits, if known. In the present study, mites with phytophagous and predatory eating habits are those of the greatest interest because of the known potential for damage of phytophagous mites, and the potential biological control agent represented by predatory mites to control populations of phytophagous mites (Watanabe, Moraes, Gastaldo, \& Nicolella, 1994; Gerson, Smiley, \& Uchoa, 2003; Gerson, 2014).

Among the mite community, the group of predatory mites showed the highest richness (16), where more than $50 \%$ of the species were common among the three cultivars (Table 1). However, the abundance of these predatory species proved to be distinct among the nectarine cultivars.

In Colombina and Josefina cultivars, 11 species (92\%) were Phytoseiidae mites. Only one individual of Armascirus sp. (Cunaxidae) was caught in Colombina, and another specimen of Proctolaelaps sp. (Melicharidae) in Josefina. The Rubro-Sol cultivar had three families of predatory mites (Table 1): Phytoseiidae (10); Melicharidae (Proctolaelaps sp.) and Stigmaeidae (Agistemus sp.) (1).

The Phytoseiidae family displayed the greatest number of species among the predatory mites (13), with approximately $2 \%$ (453) of the total mites recovered in the study. Ricoseius loxocheles (De Leon) was the most abundant species (178), representing $39 \%$ of the phytoseiidae of the present study, and it was the most abundant among the Phytoseiidae obtained from Josefina (42\%) and Rubro-Sol (49\%) cultivars (Table 1). Euseius ho was the second most numerous species (97), representing $21 \%$ of the Phytoseiidae mite found in the study. In Colombina cultivar, E. ho represented $33 \%$ of the phytoseiid mite, whereas in Josefina and Rubro-Sol, E. ho represented $17 \%$ and $21 \%$, respectively (Table 1 ).

Ricoseius loxocheles was the most abundant among the phytoseiidae under study; however, during the sampling, the occurrence was only $6 \%$ in Colombina, $10 \%$ in Josefina and $12 \%$ in Rubro-Sol. Euseius ho was the most frequent phytoseiid mite, displaying $27 \%, 23 \%$ and $31 \%$ in Colombina, Josefina and Rubro-Sol respectively. Other phytoseiid mite such as Amblyseius herbicolus (Chant), Iphiseiodes saopaulus (Denmark \& Muma) and Euseius alatus De Leon, were also the predators most commonly recovered from nectarine trees, but these predators were found in a smaller number.

The group of strictly phytophagous mites displayed only three species related to three families (Table 1). The occurrence of these mites among the cultivars under study was distinct. In Colombina, only the following species were detected: A. fockeui and T. urticae, whereas Josefina and Rubro-Sol also displayed the tenuipalpid mite Brevipalpus sp. However, the occurrence of Brevipalpus sp. was only of one individual in each cultivar. Only $A$. fockeui and T. urticae were abundant among phytophagous mites (Table 1). 
Aculus fockeui eriophyid was the most abundant mite. It accounted for $90.2 \%$ of the entire mite fauna recorded in this study $(17,409)$. Although $A$. fockeui was the most abundant mite in Rubro-Sol $(9,583)$, the populations in Colombina and Josefina were also very high in comparison to the rest of the species of mites registered, with recovery of 4,029 and 3,797 individuals, respectively.

The second most abundant phytophagous mite was $T$. urticae $(1,335)$, which accounted for $6.9 \%$ of the entire fauna of mites recovered in the study. This mite was observed in the Colombina (672), Josefina (338) and Rubro-Sol (325) cultivars. Tetranychus urticae can be considered the most frequent mite in the study, found in $69 \%$ of the samples of Colombina, $2 \%$ of Josefina and $46 \%$ of Rubro-Sol (Table 1 ).

In spite of being very abundant, the frequency of $A$. fockeui has a peculiar seasonal distribution and it is more frequent in Colombina cultivar, found in $54 \%$ of the dates sampled. In the other cultivars, $A$. fockeui displayed at least one individual in $46 \%$ the collection dates.

The other species of mites registered in the work (9) had distinct eating habits. Out of these species of mites, at least one individual was found in one of the cultivars (Table 1). Tyrophagus putrescentiae (Schramk) (Acaridae) was the most frequent species in Rubro-Sol cultivar (15\%) and Oulenzia sp. (Winterschmidtiidae) was more abundant, with a total of 32 individuals: 30 in Rubro-Sol, two in Josefina and no records in Colombina.

\subsection{Population dynamics}

The population fluctuation of the two most abundant species of predatory mites found in this study displayed a distinct standard of occurrence during the time length under study. Euseius ho was the Phytoseiidae most frequently observed $(27 \%)$ in the present study. In Colombina cultivar, it was the most abundant and frequent, since it was detected in $27 \%$ of the samples. Euseius ho was more frequent in January 2004, 2005 and 2006 , which coincides with the times when rainfall and temperature were higher (Figures 2 and 3). Josefina was the only cultivar in which $E$. ho was not the most frequent predator, found in $23 \%$ of the samples. In this cultivar, $A$. herbicolus was the most frequent predator. Still in Josefina, $E$. ho was more frequent between January and June 2004 and January 2006 (Figure 3). Rubro-Sol was the cultivar in which E. ho was the most frequent among predators $(31 \%)$. This predator was seen more often in the first and last months of 2004, and from November 2005 to January 2006 (Figure 3).

There was a significant positive correlation $(p=0.0223)$ between rainfall and the population of $E$. ho in Colombina cultivar, which suggests that this weather variable is a key factor in the population dynamics of this phytoseiid. This event can be observed in a comparison between Figures 2 and 3. In the other cultivars, no correlations were detected between $E$. ho and the weather variables analyzed.

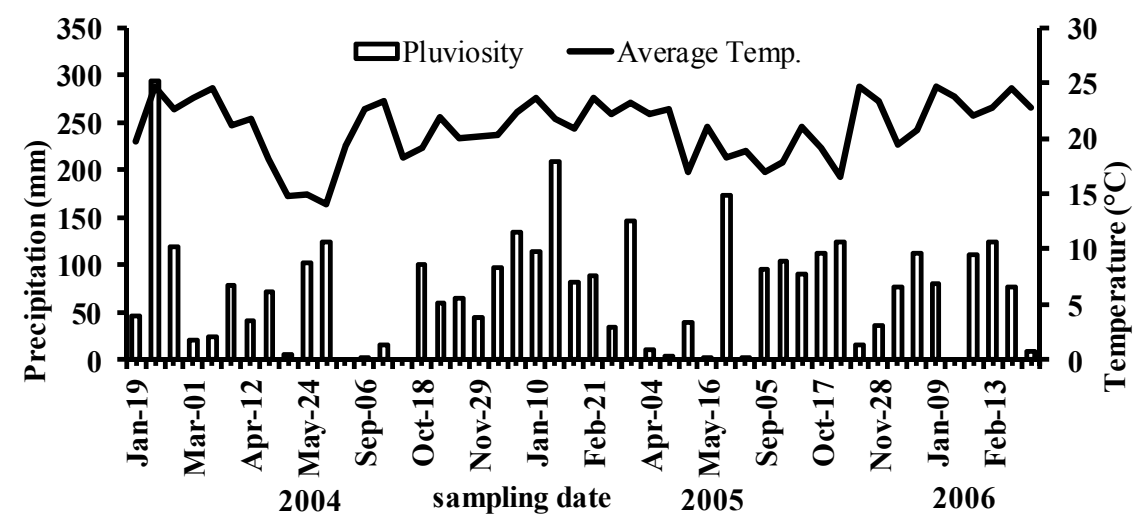

Figure 2. Cumulative rainfall and average temperature during the intervals of collections. Capão Bonito, SP, 

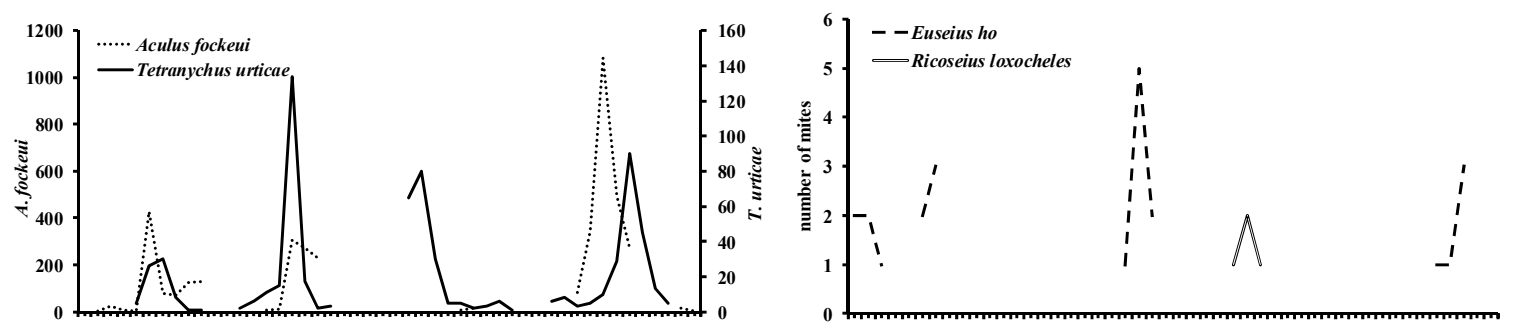

A
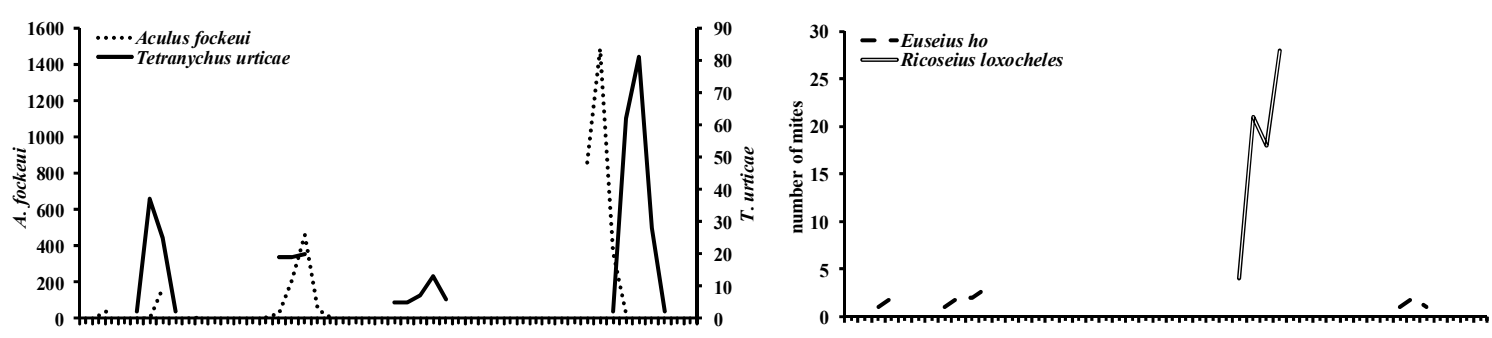

B
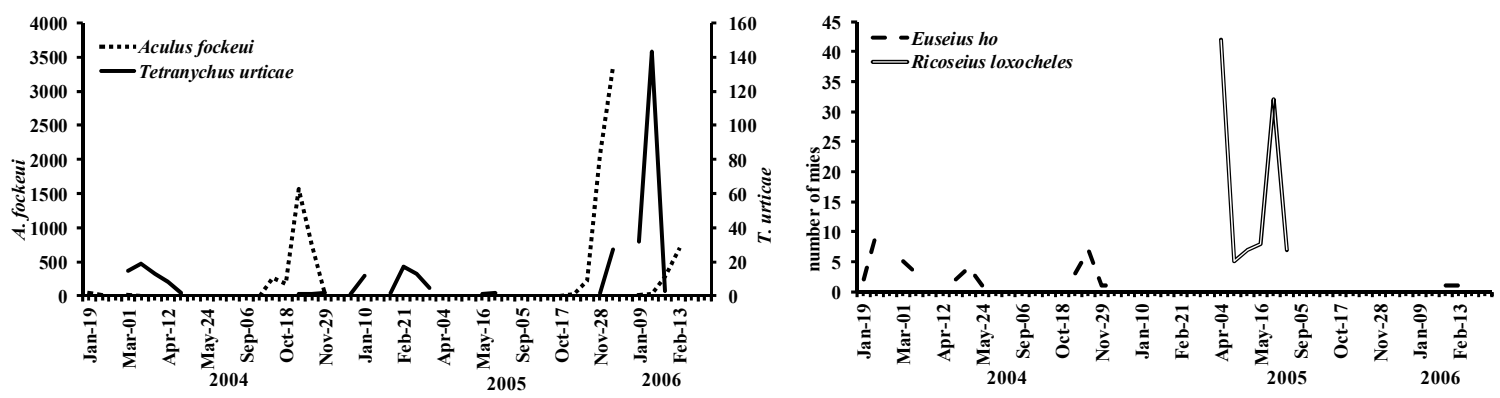

$\mathrm{C}$

Figure 3. Population dynamics of mites Aculus fockeui, Tetranychus urticae, Euseius ho and Ricoseius loxocheles from nectarines Colombina (A), Josefina (B) and Rubro-Sol (C) in Capão Bonito, SP, Brazil

Ricoseius loxocheles was found in Colombina only in 9.7\% of the samples between April and May 2005, when its smallest population among the cultivars was found (Figure 3). In Josefina, $R$. loxocheles occurred from April to June 2005, when it had its population acme (Figure 3). In Rubro-Sol, $R$. loxocheles was the most abundant predator (101), occurring at the same time period as Josefina cultivar. No correlation was detected between this species and weather variables. However, the populations of this predator displayed a common pattern of occurrence among the three nectarine cultivars under study, and do not seem to have been negatively affected by the increase in rainfall, provided that the temperature was close to $20^{\circ} \mathrm{C}$ (Figures 2 and 3).

The eriophyid A. fockeui displayed 4,029 individuals in Colombina during the study. The most abundant population was registered between February and May, November 2004 and December 2005, with a population peak on 12 December, 2005 in the three cultivars (Figure 3). The Josefina cultivar displayed the smallest number of specimens of $A$. fockeui among the nectarine trees under study $(3,797)$. The largest occurrence of $A$. fockeui was found between the last and the first months of each year, when the temperature was close to or above $20{ }^{\circ} \mathrm{C}$ (Figures 2 and 3). Rubro-Sol displayed the greatest abundance of $A$. fockeui in the study $(9,583)$. In spite of the high number of this eriophyid, its frequency was similar to the frequency observed in Josefina cultivar (46\%). Aculus fockeui displayed 3,356 individuals in Rubro-Sol cultivar on 12 December, 2005 (Figure 3). No significant correlations were detected between the population of $A$. fockeui and the weather variables analyzed.

Tetranychus urticae was recovered from 25 out of the 48 samples taken. Colombina was the cultivar in which spotted mites displayed the greatest frequency and abundance, without displaying definite periods to occur. The population peaks of T. urticae were observed on 1 November, 2004, 21 March, 2005 and 9 January, 2006. 
Rainfall and temperature observed on these dates were respectively $59 \mathrm{~mm}$ and $22{ }^{\circ} \mathrm{C}, 147 \mathrm{~mm}$ and $23{ }^{\circ} \mathrm{C}$, and $81 \mathrm{~mm}$ and $25^{\circ} \mathrm{C}$ (Figures 2 and 3). In Josefina, T. urticae displayed 338 individuals and its frequency was the smallest among the cultivars. The occurrence of spotted mites in Josefina was limited to 4 isolated periods, with the greatest abundance on 16 January, 2006, with 81 individuals recovered (Figures 2 and 3). Rubro-Sol cultivar displayed the second greatest abundance of $T$. urticae among the cultivars ( 325 specimens), with its peaks also on 16 January, 2006, when there was no rainfall and the mean temperature was approximately $24{ }^{\circ} \mathrm{C}$ (Figures 2 and 3). The populations of spotted mites displayed distinct patterns among frequency and abundance in the cultivars analyzed. In Josefina, this species was more abundant, and in Rubro-sol it was less abundant (Figure 3).

No significant differences were found among the cultivars when submitted to Anova analysis. Table 2 shows the results of this analysis more clearly and determines that the means followed by the same letter do not differ statistically from each other.

Table 2. Statistical analyses (ANOVA) of the four main representative mite species among phytophagous and predator mites, recovered from leaves of nectarines 'Colombina', 'Josefina' and 'Rubro-sol'. Capão Bonito, SP, Brazil.

\begin{tabular}{lcccc}
\hline \multicolumn{1}{c}{ Species } & Colombina & Josefina & Rubro-sol & $\mathrm{F}$ \\
\hline Aculus fockeui & $83.94 \mathrm{a}$ & $79.10 \mathrm{a}$ & $199.64 \mathrm{a}$ & $1.42^{\mathrm{ns}}$ \\
Tetranychus urticae & $14.00 \mathrm{a}$ & $7.04 \mathrm{a}$ & $6.77 \mathrm{a}$ & $1.68^{\mathrm{ns}}$ \\
Euseius ho & $0.52 \mathrm{a}$ & $0.60 \mathrm{a}$ & $0.89 \mathrm{a}$ & $0.74^{\text {ns }}$ \\
Ricoseius loxocheles & $0.08 \mathrm{a}$ & $1.52 \mathrm{a}$ & $2.10 \mathrm{a}$ & $1.73^{\text {ns }}$ \\
\hline
\end{tabular}

Means within rows followed by the same letter were not significantly different by Tukey's test at ( $\mathrm{p}<$ $0.05)$.

\section{Discussion}

The large abundance $(19,297)$ of mites split among the different families of the mite fauna indicates that this group of arthropods deserves attention in terms of pest management in nectarine cultivars. Some species of mites can reach the status of pests, such as $A$. fockeui, which is considered a universal pest in peach, nectarine, plum and almond trees (Abou-Awad, AL-Azzazy \& El-Sawi, 2010). However, the species of predatory mites can be important allies in programs of biological control of pests (Watanabe et al., 1994; Gerson, 2014) either due to strategies of inundation or conservationist release.

The high number of mite families (14) recovered in the present study reflects a relatively common result observed in the surveys of the mite fauna of peach (Prunus persica (L.) Batsch) in Brazil: 16 families (Montes et al., 2010), 14 families (Eichelberger, Johann, Majolo \& Ferla, 2011), 17 families (Montes et al., 2011), 12 families (Montes et al., 2012).

In spite of the large diversity of families and species registered, it was found that only the frequency of $T$. urticae (52\%) was above $50 \%$ among the three cultivars studied, whereas the second most frequent species was $A$. fockeui $(48 \%)$. The frequency of the other species was below $28 \%$. The other species occurred less often, and in some cases only one individual was found. Eichelberger et al. (2011) also found species of mites that are not very constant in the south of Brazil and different from the present study. B. phoenicis, Tetranychus ludeni Zacher and Typhlodromalus aripo De Leon, were predominant.

Although $R$. loxocheles was registered as the most abundant predator in the present study, this Phytoseiidae did not showed constancy and neither correlation with phytophagous mites. It is possible that this mite is not an efficient predator of other mites.

Ricoseius loxocheles has no preference for a host plant in particular. This phytoseiidae is known from vegetable materials collected in Brazil, in Florida (USA), Colombia, Costa Rica, Guadalupe, Honduras, Martinique (Flechtmann, 1967; Denmark \& Muma, 1973; Flechtmann, 1976; Moraes, Mesa \& Braun, 1991; Denmark, Evans, Aguilar, Vargas \& Ochoa, 1999; Moraes, Kreiter \& Lofego, 1999). It is believed that its eating habits contributed to its wide distribution, since this predator does not need to have a specific host or food to survive.

Euseius ho was the most frequent phytoseiid mite, with a mean of $27.08 \%$ of occurrence among the 3 cultivars. With this, the hypothesis arises that this species may be a potential agent of biological control of phytophagous 
mites in Rosaceae. Moreover, in the present study, this predator displayed a positive correlation with rainfall in Colombina cultivar. This suggests that its population increased with high rainfall. This fact may also interfere in future programs of biological control.

In peach trees in Brazil, Montes et al. (2010) found that E. citrifolius and E. concordis were the most abundant and frequent predators in Presidente Prudente (SP). Several species of the Euseius genera were registered in the different agroecosystems where studies of the fauna of mites of Prunus species were made (Castagnoli \& Nannelli, 1987; Montes et al., 2010; 2011; 2012; Sonoda et al., 2012).

Aculus fockeui has been frequently reported as the important species of phytophagous mites in stone Rosaceae (Ferreira \& Carmona, 1997; Kondo \& Hiramatsu, 1999; Montes et al., 2010; 2011). The results on population fluctuation of the key species of mites observed in the present work coincide with the data from studies conducted by Montes et al. $(2010 ; 2012)$, in which $A$. fockeui was the most abundant pest mite in all cultivars assessed in the western region of the State of São Paulo. In these studies, the greatest frequency of $A$. fockeui also took place in December, when the mean temperature was close to $20^{\circ} \mathrm{C}$.

According to Abou-Awad et al. (2010), the appropriate temperature in the orchards, better eating conditions and absence of a natural predator would have led to quick growth of $A$. fockeui, which is considered a disaster to nectarine and peach trees. These authors studied the biology of $A$. fockeui in Egypt and concluded that this eriophyid mite was able to develop successfully from egg to adult at temperatures between 21 and $32{ }^{\circ} \mathrm{C}$ and $70 \%$ relative humidity. The environmental parameters such as temperature and relative humidity are intrinsic to the development of these phytophagous mites, and can explain the significant differences in population fluctuation of this species observed in this study.

Another factor that would explain the pattern of cyclic occurrence of $A$. fockeui is the hibernation strategy of this mite, which coincides with the fall of the leaves of Rosaceae of temperate climate. Females in diapause hide in buds or cracks in branches and barks, and resume their activity when plant sprouts start to expand in spring (Beers \& Oldfield, 1993). Mites in diapause were found more often in sprouts of host plants with deciduous leaves (De Lilo \& Shoracka, 2010). In Brazil, there are no information about the hibernation behavior of $A$. fockeui.

Tetranychus urticae was the second most numerous phytophagous mites in this study. Montes et al. (2010) also observed this behavior in peach trees of the region of Presidente Prudente (SP). Ferreira and Carmona (1997), in peach trees in Portugal there was abundance of $41.6 \%$ of A. fockeui and $20 \%$ of Tetranychus cinnabarinus (Boisduval). According to Moraes and Flechtmann (2008), T. urticae is the most important species in Brazil among the 6 species of tetranychid mite with economic significance since they have a large number of hosts and can cause severe damage to many crops. However, more studies are required to know the potential for damage that this species can cause in nectarine trees.

In this study the mite communities of Colombina and Josefina cultivars were similar. Rubro-Sol was distinct as to diversity and abundance in comparison to the other nectarine cultivars. These results suggest that mites have a preference for a certain cultivar rather than others. According to Gerson et al. (2003), the chemical aspects and the physical structure of host plants may affect the growth rate of pest mites.

The three cultivars studied had characteristics of early growth, which excludes the possibility that mites prefer distinct growing seasons. However, differences in plant structure such as shape of the tree top (which favors control of humidity inside the tree), the presence of villosities in branches used as hiding place, or even morphological aspects of leaves such as chemical composition, water contents or even thickness can be key characteristics for mites to prefer certain cultivars.

New studies oriented to determine the key factors are involved on attractiveness and dynamics of mite fauna in Rosaceae. These studies will help to support future programs for genetic breeding and integrated pest management in nectarine trees.

\section{References}

Abou-Awad, B. A., AL-Azzazy, M. M., \& El-Sawi, A. (2010). The life - history of the peach silver mite, Aculus fockeui (Acari: Eriophyidae) in Egypt. Arch. Phytopathol., 43(4), 384-389. http://dx.doi.org/10.1080/03235400701806427

Ayres, M., Ayres Jr, M., Ayres D. L., \& Santos, A. A. S. (2007). BioEstat 5.0. - Aplicações estatísticas nas áreas das Ciências Biomédicas. Sociedade Civil Mamirauá: Belém, Pará-Brasil. p. 324. 
Barbosa, W., Ojima, M., Campo-DallOrto, F. A., \& Martins, F. P. (1993). Melhoramento do pessegueiro para regiões de clima subtropical-temperado: realização do Instituto Agronômico no período de 1950-1990. Instituto Agronômico, Campinas. p. 30.

Beers, E. H., \& Oldfield, G. N. (1993). (Acari: Eriophyidae) Plum nursery mite Plum rust mite Cherry rust mite Aculus (Phyllocoptes) fockeui (Nalepa and Trouessart) Peach silver mite Aculus cornutus (Banks). Washington State University. Retrieved from http://www.tfrec.wsu.edu/pages/opm/PRU

Castagnoli, M., \& Nannelli, R. (1987). Further observations on populations trend of mites in an experimental peach meadow orchard in central Italy. Firenze. Redia, 70,121-133.

Castagnoli, M., \& Oldfield, G. N. (1996). Other fruit trees and nut trees. In: Lindquist, E. E., Sabelis, M. W. and Bruin, J., (Eds.) Eriophyoid mites - their biology, natural enemies and control (pp. 543-560). Amsterdam. Elsevier. http://dx.doi.org/10.1016/S1572-4379(96)80034-0

De Lillo, E., \& Skoracka, A. (2010). What's "cool" on eriophyoid mites?. Exp. Appl. Acarol., 51, 3-30. http://dx.doi.org/10.1007/s10493-009-9297-4

Denmark, H. A., Evans, G. A., Aguilar, H., Vargas, C., \& Ochoa, R. (1999). Phytoseiidae of Central America (Acari: Mesostigmata). Indira Publishing House, West Bloomfield. p.125.

Denmark, H. A., \& Muma, M. H. (1973). Phytoseiid mites of Brazil (Acarina: Phytoseiidae). Rev. Brasil. Biol. $33,235-276$.

Eichelberger, C. R., Johann, L., Majolo, F., \& Ferla, N. J. (2011). Mites fluctuation population on peach tree (Prunus persica (L.) Batsch) and in associated plants. Rev. Bras. Frutic., 33, 765-773. http://dx.doi.org/10.1590/S0100-29452011005000102

Ferreira, M. A., \& Carmona, M. M. (1997). Acarofauna do pessegueiro em Portugal. Bol. San. Veg. Plagas., 23, 473-478.

Flechtmann, C. H. W. (1967). Ácaros de plantas frutíferas. Escola Superior de Agricultura Luiz de Queiroz/Universidade de São Paulo, Piracicaba, Brasil, Boletim Técnico-Cientifico. No. 30. p.24. http://dx.doi.org/10.1590/S0071-12761967000100028

Flechtmann, C. H. W. (1976). Observações sobre dois ácaros (Mesostigmata, Acari) de vida livre. An. Soc. Entomol. Brasil., 5, 95-96.

Flechtmann, C. H. W. (1979). Ácaros de importância agrícola. São Paulo: Livraria Nobel, p.189.

Gallo, D., Nakano, O., Silveira Neto, S., Carvalho, R. P. L., Batista, G. C. de, Berti Filho, E., ... Omoto, C. (2002). Entomologia agrícola (10th Ed.). FEALQ, Piracicaba, p. 920.

Gerson, U. (2014). Pest control by mites (acari): present and future. Acarologia, 54, 371-394. http://dx.doi.org/10.1051/acarologia/20142144

Gerson, U., Smiley, R. L., \& Uchoa, R. (2003). Mites (Acari) for pest control. Blackwell Science, Oxford. P. 539. http://dx.doi.org/10.1002/9780470750995

Hammer, Ø., Harper, D. A. T., \& Ryan, P. D. (2001). PAST: Paleontological statistics software package for education and data analysis. Palaeontol. Electron., 4, 9.

Jeppson, L. R., Keifer, H. H., \& Baker, E. W. (1975). Mites injurious to economic plants. Berkeley: University of California Press. p. 614.

Keifer, H. H., Baker, E.W., Kono, T., Delfinado, M., \& Styer, W. E. (1982). An illustrated guide to plant abnormalities caused by eriophyid mites in North America. United States Department of Agriculture, Washington. p. 178.

Kondo, A. E., \& Hiramatsu, T. (1999). Analysis of peach tree damage caused by each silver mite, Aculus fockeui (Nalepa e Trouessart). Jpn. J. Appl. Entomol. Zool., 43, 189-193. http://dx.doi.org/10.1303/jjaez.43.189

Montes, S. M. N. M., Raga, A., Boliani, A. C., Mineiro, J. L. C., \& Santos, P. C. dos. (2010). Composição acarina em diferentes cultivares de pessegueiros [Prunus persica (L.)] em Presidente Prudente, Estado de São Paulo. Rev. Bras. Frut., 32, 414-422. http://dx.doi.org/10.1590/S0100-29452010005000050

Montes, S. M. N. M., Raga, A., Boliani, A. C., Mineiro, J. L. C., \& Santos, P. C. dos (2011). Effect of fungicides on the mite fauna of Prunus persica L. cultivars in Presidente Prudente, SP, Brazil. J. Plant Prot. Res., 5, 285-293. http://dx.doi.org/10.2478/v10045-011-0047-3

Montes, S. M. N. M., Raga, A., Boliani, A. C., Mineiro, J. L. C., \& Santos, P. C. Dos. (2012). Mite Fauna (Arachnida: Acari) on Peach Cultivars in Presidente Prudente, São Paulo, Brazil. J. Plant Stud. 1, 173-179.

Moraes, G. J., Mesa, N. C., \& Braun, A. (1991). Some phytoseiid mites of Latin America (Acari: phytoseiidae). Int. J. Acarol., 17, 117-139. http://dx.doi.org/10.1080/01647959108683892

Moraes, G. J., Kreiter, S., \& Lofego, A. C. (1999). Plant mites (Acari) of the French Antilles. 3. Phytoseiidae (Gamasida). Acarologia, 40, 237-264. 
Moraes, G. J., \& Flechtmann, C. W. H. (2008). Manual de acarologia: acarologia básica e ácaros de plantas cultivadas no Brasil. Ribeirão Preto: Holos, p. 288.

Ojima, M., Campo Dall'orto, F. A., Barbosa, W., Tombolato, A. F. C., Martins, F. P., \& Rigitano, O. (1986). Josefina: nova nectarina de polpa branca. In: Congresso Brasileiro de Fruticultura, 8., Brasília, 1986. Anais. Brasília: $S B F$. ., 2, 417-419.

Raseira, M. Do, \& Centellas-Quezada, C. B. E. A. (2003). Pêssego: Produção. Embrapa Clima Temperado (Pelotas, RS). - Brasília: Embrapa Informação Tecnológica. p. 162.

Rigitano, O., Ojima, M. and Campo Dall'orto, F. A. (1975). Comportamento de novas seleções de pêssegos introduzidos da Flórida. Campinas: Instituto Agronômico, (Circular, 46). p. 12.

Silva, F. A. S., \& Azevedo, C. A. V. (2006). A New Version of The Assistat-Statistical Assistance Software. In: World Congress on Computers in Agriculture, 4, Orlando-FL-USA: Anais... Orlando: ASABE. 393-396.

Sonoda, S., Kohara, Y., Siqingerile, Toyoshima, S., Kishimoto, H., \& Hinomoto, N. (2012). Phytoseiid mite species composition in Japanese peach orchards estimated using quantitative sequencing. Exp. Appl. Acarol., 56, 9-22. http://dx.doi.org/10.1007/s10493-011-9485-x

Watanabe, M. A., Moraes, G. J. de, Gastaldo Jr, I., \& Nicolella, G. (1994). Controle biológico do acaro rajado com ácaros predadores fitoseídeos (Acari: Tetranychldae, Phytoseiidae) em culturas de pepino e morango. Sci. Agric., 51, 75-81. http://dx.doi.org/10.1590/S0103-90161994000100012

\section{Copyrights}

Copyright for this article is retained by the author(s), with first publication rights granted to the journal.

This is an open-access article distributed under the terms and conditions of the Creative Commons Attribution license (http://creativecommons.org/licenses/by/3.0/). 